\title{
PORTO ALEGRE SUSTAINABLE INNOVATION ZONE - THE STRATEGY OF SMART CITY DEVELOPMENT AS EXEMPLIFIED BY THE BRAZILIAN CITY IN RELATION TO POZNAŃ (POLAND)
}

\author{
OBSZAR ZRÓWNOWAŻONEJ INNOWACJI PORTO ALEGRE - STRATEGIA \\ ROZWOJU SMART CITY NA PRZYKŁADZIE BRAZYLIJSKIEGO MIASTA \\ W ODNIESIENIU DO POZNANIA (POLSKA)
}

\section{Ewa Angoneze-Grela}

MSc. Arch.

Author's Orcid number: 0000-0001-9897-8573

Politechnika Poznańska

Wydział Architektury

Instytut Architektury i Planowania Przestrzennego

\begin{abstract}
Porto Alegre, a city in south Brazil, was a pioneer in participatory budgeting in the 1990s, and a decade later it hosted the World Social Forum. These days Porto Alegre is the first place in the world with a Sustainable Innovation Zone. The goal of this endeavour is to transform the city into the most innovative and sustainable city in Latin America by 2030. In the article, the author examines the projects completed to date and the entities involved. Then, the author compares the experiences of Porto Alegre and Poznań.
\end{abstract}

Key words: innovation, smart city, sustainable development.

\section{STRESZCZENIE}

Porto Alegre, miasto w południowej Brazylii, było w latach 90. XX wieku pionierem w dziedzinie budżetu partycypacyjnego, dekadę później odbywało się tam Światowe Forum Społeczne. Obecnie Porto Alegre jest pierwszym miejscem na świecie, w którym powstał Obszar Zrównoważonej Innowacji. Celem tego przedsięwzięcia jest transformacja miasta w najbardziej innowacyjne i zrównoważone miasto w Ameryce Łacińskiej do 2030 roku. W artykule autorka przygląda się zrealizowanym do tej pory projektom oraz zaangażowanym w nie podmiotom W dalszej części artykułu autorka porównuje doświadczenie Porto Alegre z Poznaniem.

Słowa kluczowe: innowacja, smart city, zrównoważony rozwój. 


\section{INTRODUCTION}

Sustainable development and innovation are the two trends which define the present and the future of the 21st-century cities. The organisation of life in urban centres has an undeniable impact on the natural environment and global climate processes. It is believed that megacities are the future of civilisation, so we should perceive them as a chance and not a threat. It is them that should be the green future of our planet. If so, sustainable development becomes a pressing need to resolve the problems of cities, as it is urban centres that use the largest amounts of the world's resources and generate the most appalling wastefulness (Leite, 2012, p. 14). Combined with innovative technology and the multidimensional involvement of a conscious society, sustainable development may become an effective tool for building the smart cities of the future. The article presents an international project brought into existence in Porto Alegre-the capital of the Brazilian state of Rio Grande do Sul. The Sustainable Innovation Zone (Port. Zona de Inovação Sustentável - ZIS), which was created there in 2015, implements the principles of the Leapfrog strategy with the aim to transform Porto Alegre into the most innovative and sustainable city in Latin America by 2030 . The article analyses the main goals and plans of the ZISPOA (Zona de Inovação Sustentável Porto Alegre), the projects and entities involved in their completion. The Porto Alegre Sustainable Innovation Zone is then compared with the Smart City Poznań initiative, and a new definition of a smart city is proposed.

\section{MATERIALS AND METHODS}

The aim of this article is to verify the social actions that took place in the city of Porto Alegre under the ZISPOA in the years 2015-2021 and analyse the nature of the entities involved. The goal was to check whether the initiatives undertook by the ZISPOA actually engage various social groups in the city and how they are perceived by the locals. The next stage of the research was to compare the experiences of the Brazilian city with similar initiatives carried out in the capital of Greater Poland in the time period in question.

The method was based on library research and the monitoring of the websites devoted to the initiatives completed under the SIZ, including the official news services of the ZISPOA, Global Urban Development, media coverages and the social media accounts of the ZISPOA, startups (such as Elysia Energia Solar, Oz Engenharia, Point, Young Energy, MVM Technologies, Ecotelhado), NGOs (e.g. Acossiação Cultural Vila Flores, Mobicidade, Pedal das Gurías, Solidariedade, Pacto Alegre) and enterprises (3C Arquitetura e Urbanismo, Loop, Marquise 51 Centro Criativo, Pulsar and others). The entities involved in the ZISPOA projects have been systematised and assigned to the following categories: Governmental Organisations, NGOs, Universities, Startups / Business Incubators, Enterprises. Commentaries by numerous participants of the initiatives complemented with media coverages allowed the author of the research project to become acquainted with various points of view and understand the local community's perception of the ZISPOA projects. The proper evaluation of the SIZ's impact on the functioning of the city must have involved more than the examination of the report on implemented projects. The author has consulted the Connected Smart Cities rankings, which evaluate all Brazilian cities in a number of categories in the years 2015-2021. Her selection of categories corresponds to the goals of the ZISPOA: Technology and Innovation, Entrepreneurship and the general ranking, which has allowed her to identify some trends in the evaluation of the city over the last six years. It is worth mentioning that the author is familiar with the city of Porto Alegre she visited it, including the ZISPOA, several times before 2019. Unfortunately, the epidemiological situation in the years 2020-2021 has made it impossible for her to revisit it and verify the effects of that activity in situ. Nevertheless, the general conclusions are based not only on the aforementioned research, but also on her personal experience from before the pandemic.

Another task that the author has undertaken is an attempt to compare the experiment of Porto Alegre with Poznań. In order to achieve that, two figures have been created-the diagrams present the administrative boundaries of both cities as well as the institutions connected with the development of entrepreneurship and innovation (for Poznań) and the area covered by the project with key facilities, such as university campuses, parks, food markets, hospitals, churches, theatres (for the ZISPOA). The author has also listed Poznań's initiatives resulting from the city's aspiration to acquire the status 
of a smart city, e.g. a 3D model of the city, the Smart City Poznań programme and mobile application, participatory budgeting and other activities comparable to the ZISPOA's. In the case of Poznań, she has analysed the city's position in the international Globalization and World Cities Research Network ranking as well as the Report on the State of the City of Poznan for 2020 drawn up by the City Council. Personal experiences and observations regarding this urban centre result from the fact that the author of the article is a resident of Poznań.

\section{PORTO ALEGRE}

Porto Alegre is an urban centre, inhabited by almost 1.5 million people, encompassing an area of $500 \mathrm{~km} 2$ (IBGE, 2021), located by the picturesque lake of Guaiba (Figures 1, 2). The lake is the landmark of the cityscape and, along with Lagoa dos Patos, makes up the largest navigable lagoon of South America. With its international Aeroporto Salgado Filho airport, the city is an important transport hub in the region and a prominent centre for trade, industry, culture and education. Established in 1809, it is the centre of the gaúcho culture (gaúcho - a South-American cowboy working on the pampas of Argentina, Uruguay, Paraguay, Chile and southern Brazil. Colloquially - a resident of the state of Rio Grande do Sul). The city is home to several universities, of which the leading one is the UFRGS (Universidade Federal do Rio Grande do Sul) federal university.

Porto Alegre was internationally noticed in the 1990 s thanks to its pioneering implementation of participatory budgeting. This mechanism of participatory democracy originated in Pelotas - another city of the Rio Grande do Sul state - where in 1983 Bernardo de Souza - the then-mayor of the city brought into effect a programme under the slogan All power comes from the people, which was in fact the precursor of the idea of participatory budgeting. The programme encourages the residents of the city to take part in the discussions and decision-making processes regarding local matters, particularly education-related (Streck, Pitano, Moretti, 2017, p. 13). Following its success, the idea was copied and structured in the capital city of the state - Porto Alegre - to then acquire the status of a state law under the name of participatory budgeting (Port. orçamento participativo). The innovative solution received publicity throughout the world, and similar initiatives were introduced in numerous cities in Europe, Asia, Africa and North America.

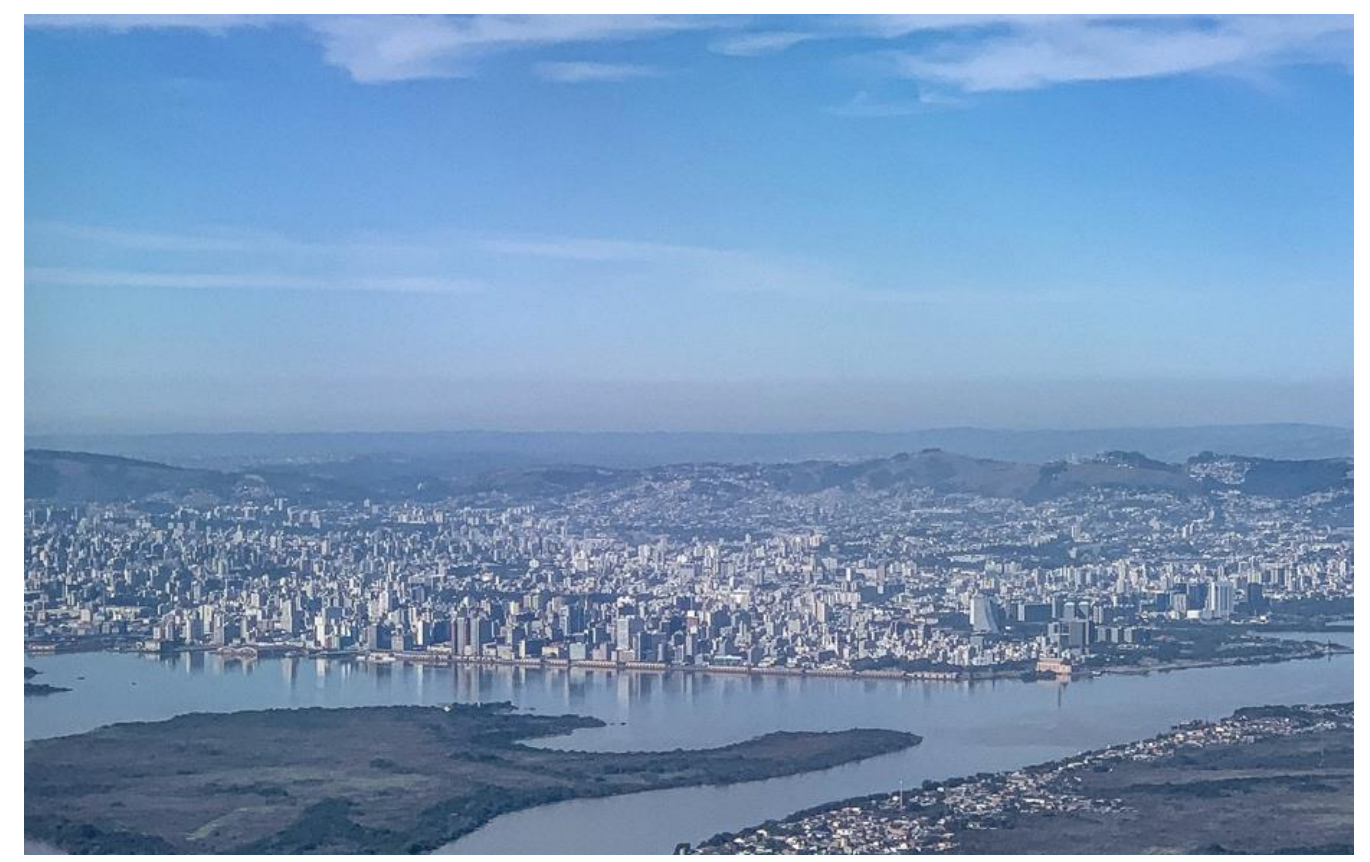

Fig. 1. Skyline of Porto Alegre from the mouth of the Jacuí river, aerial photograph; Source: @E. Angoneze-Grela Ryc. 1. Panorama miasta Porto Alegre od strony ujścia rzeki Jacuí, zdjęcia lotnicze; Źródło: @E. Angoneze-Grela 
Porto Alegre may be considered the world's largest testing ground for direct democracy of international significance, which found its confirmation in acknowledging this form of local governance as the role model during the UN Conference Habitat II in Istanbul in 1996 (Kuriata, 2013, p. 41). Some Polish cities took an interest in this solution and, starting with Sopot in 2011, participatory budgeting has been enjoying increasing popularity as an instrument of direct democracy in a growing number of Polish cities. It is a clear example of the fact that locally developed experiences may impact the organisation of city life on a global scale.
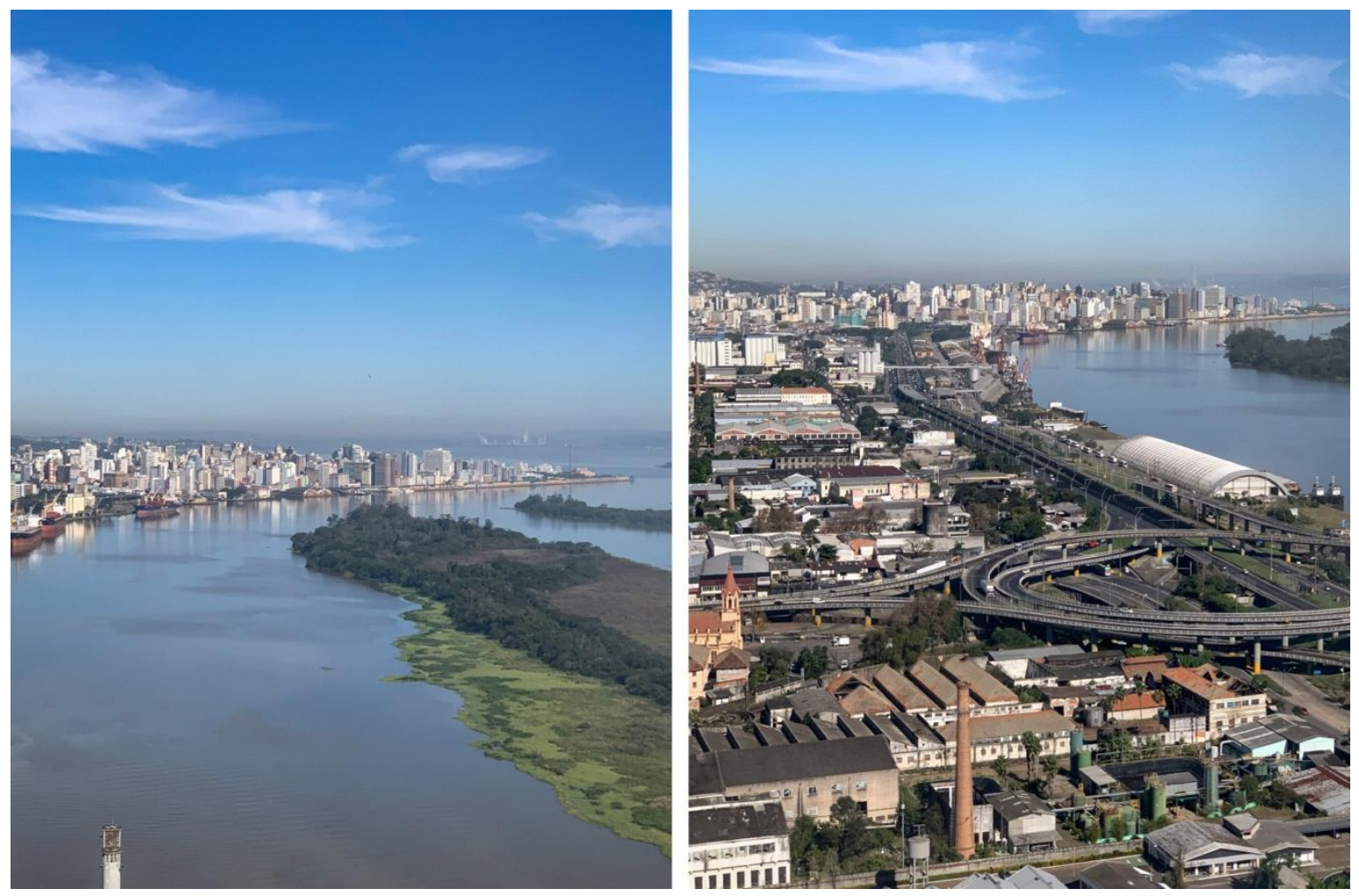

Fig. 2. Skyline of Porto Alegre from the mouth of the Jacuí river, with the archipelago, transport node, Av. Castelo Branco; aerial photographs; Source: $\mathrm{OE}$. Angoneze-Grela

Ryc. 2. Panorama miasta Porto Alegre od strony ujścia rzeki Jacuí, widoczny archipelag, węzeł komunikacyjny, Av. Castelo Branco, zdjęcia lotnicze; Źródło: @E. Angoneze-Grela

Another argument for the capital of Rio Grande do Sul having a considerable influence on the vision of the cities of the future is the World Social Forum - an international event of global significance held under the slogan Another world is possible. In the years 2001-2003 the three first editions of this event took place in Porto Alegre, which attracted hundreds of thousands of participants from all over the world. In the 2000s the event was considered a counterbalance to the World Economic Forum in Davos (Wiechetek, 2020, p.30), and Le Monde Diplomatique announced that the new 21st century has just begun in Porto Alegre [5] (p.26). It was no coincidence that in that very city, based on the above experiences, the new initiative under the name Porto Alegre Sustainable Innovation Zone (ZISPOA) was established in 2015. Financially supported by the World Bank, the Global Urban Development organisation thus commenced works on implementing the Leapfrog economic strategy. Initially, this term referred to the economy of innovation and was associated with the notion of com- 
panies' technological leap. Recently, this idea has been embraced by the theory of sustainable development. According to it, developing countries can abandon old technologies and leapfrog, shunning the solutions adopted by developed countries in the past. Instead of implementing production structures based on the intensive use of non-renewable natural resources, developing countries may now invest in production based on renewable energy sources such as solar, wind or water energy (Scatolin, Misael, 2011, p.7). Marc Weiss, the CEO of Global Urban Development, started cooperating with Porto Alegre in 2011 when the Brazilian Agency for Industrial Development (Agência Brasileira de Desenvolvimento Industrial - ABDI) along with the Federation of Industries of the State of Rio Grande do Sul (Federação das Indústrias do Rio Grande do Sul) asked him for help in working out a development strategy for the city and the state (Weiss, Sedmak-Weiss i Rodriguez, 2021). He later collaborated with local organisations and universities, making the World Bank's investments that supported the strategy advance of Rio Grande do Sul's economic development. Based on that cooperation and the exchange of experiences, the first Sustainable Innovation Zone (ZISPOA) in South America was established. Then, the idea was recreated in another Brazilian city - Santo Ângelo (ZISSAN), the city of Panamá in Panama (ACTA), London, New York (ZISs - Brooklyn) and Western Sydney, Australia. The main idea behind a Sustainable Innovation Zone is to create a concentrated model of sustainable development and innovation as a process of city consolidation with the focus on interpersonal relationships and smart problem-solving. Coordinated by Global Urban Development, the Sustainable Innovation Zones movement has already gathered over 700 leaders and specialists in 60 countries around the world.

\section{ZISPOA}

ZISPOA (Porto Alegre Sustainable Innovation Zone) is the first important phase of implementing the Leapfrog Economic Strategy by the World Bank for the city and state of Rio Grande do Sul. In 2015 the authorities delimited a downtown area, which included parts of two neighbourhoods: Independência and Floresta (Fig. 3).

The choice of this location was connected with the vicinity of university campuses, technology parks and business incubators, which was supposed to create the magnet effect attracting talented and creative professionals from around the globe. The precisely defined limits of the city area allowed the trailblazers to concentrate state-of-the-art technology experiments aimed to reduce and recycle materials and effectively utilise natural resources. Such a way of thinking should allow people to achieve prosperity by improving the quality of life, earning and saving more money, having better workplaces, all the while fulfilling the decisions of the Paris Agreement and the New Urban Agenda signed in Quito in 2016. In the next phase of the project, its area was expanded by eight districts: Azenha, Bom Fim, Centro Histórico, Cidade Baixa, Farroupilha, Rio Branco, Santa Cecilia and Santana (Figure 3). Thus the ZISPOA now included: the largest city park, two federal universities and three higher schools, six hospitals, the oldest and largest Brazilian organic food market, four private companies and numerous educational, cultural and religious institutions. Since its very beginning, the ZISPOA has been closely cooperating with UFRGS scholars and students with the aim that the university become the global leader of innovation by 2030. In 2017 the City Council unanimously voted for an official establishment of the Sustainable Innovation Zone and its boundaries, and started actively cooperating to include the ZISPOA in the city's spatial development plan (ZISPOA Info, 2021).

The Sustainable Innovation Zone is based on six key fields:

- Innovation and technology;

- Entrepreneurship and start-ups;

- Sustainability and resource efficiency;

- Creativity and collaboration;

- Participatory community management;

- Business-friendly environment. 


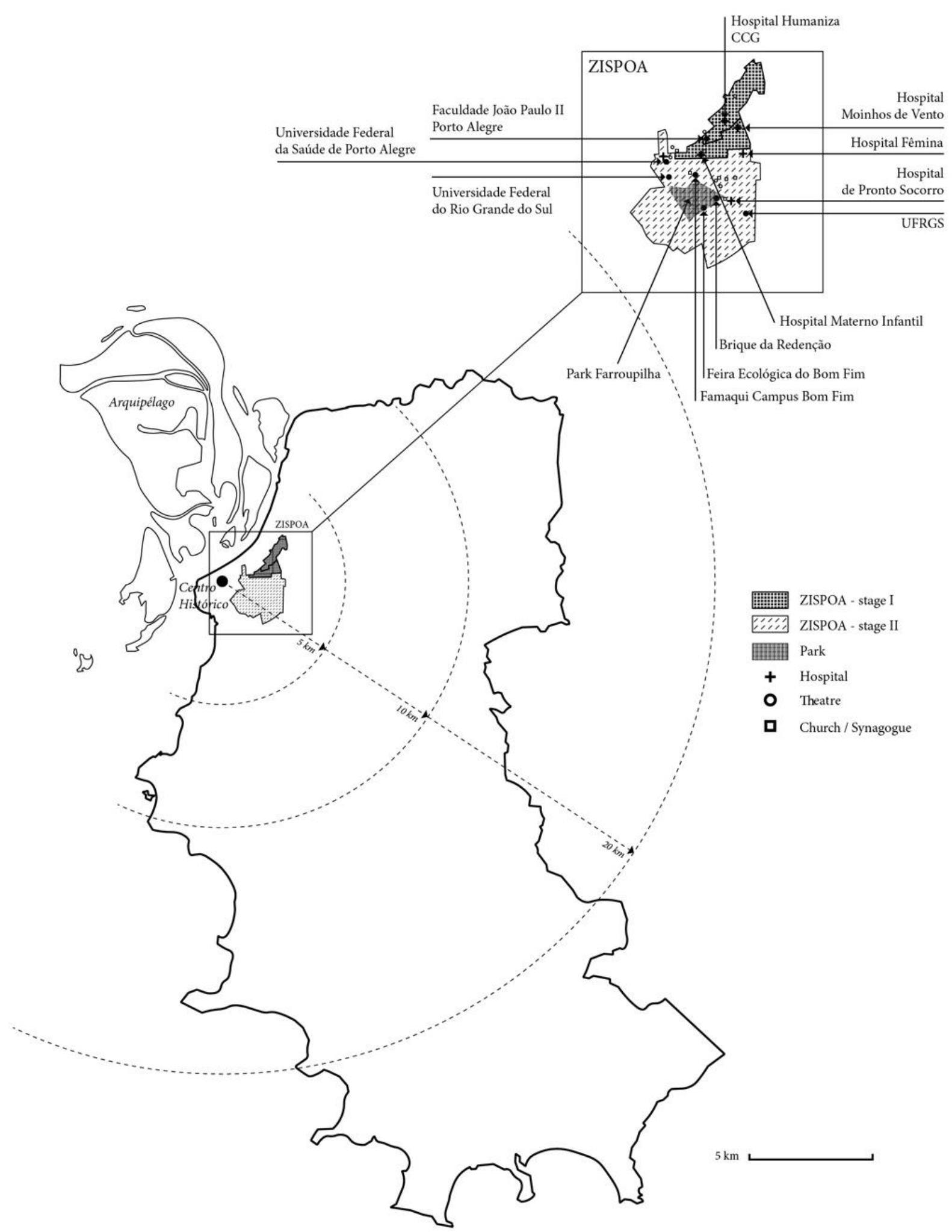

Fig. 3. Diagram presenting the limits of Porto Alegre city and ZISPOA (stages I and II); Source: author's own work based on Google Maps and ZISPOA map.

Ryc. 3. Schemat przedstawiający granice miasta Porto Alegre, zakres ZISPOA (I i II etap), Źródło: opracowanie własne na podstawie Google Maps i mapy ZISPOA 
The goal of the ZISPOA is to transform the Sustainable Innovation Zone into an area that is South America's champion in terms of: the use of solar energy, energy efficiency, digital communication, renewable-energy-based technology friendliness and bicycle friendliness. An important field of operation is education and the involvement of the academia, including the questions related to teaching about the idea of sustainable development. Appropriate courses included in the curriculum guarantee that the graduates will be well prepared to enter the job market.

According to Valéria Café, the research director of the Brazilian Association of Sustainability Professionals, People educated in sustainability are now perceived as strategic professionals in the face of water and energy crises. They stand out from the crowd because they can show companies how to lower costs (Gentil, 2018, p.39). Another goal of the ZISPOA programme is to enable growth to startups, young university enterprises, technicians, students and activists. Thanks to their energy and creativity, this new generation may change the urban space into intelligent cities of the future. It is estimated that the majority of people working in the ZISPOA are young: approximately $42 \%$ are people not older than 35, from various educational backgrounds (usually higher education), mainly graduates in such disciplines as Administration, Engineering or Environmental Management (Gentil, 2018, p. 39). One of the largest initiatives engaging the academia is ZISProf-over 150 university teachers from 16 higher schools are involved in the project as science advisers. The researchers offer their students help in finding projects and scientific research carried out within the Sustainable Innovation Zone.

According to Marc Weiss, the CEO of GUD, ZISPOA projects generate such trends in the urban space as: the widespread use of technology for innovation, a strong sense of sustainable development as the goal to be achieved, the pursuit of introducing changes, small modifications that bring quick and evident benefits (agile delivery / quick wins), or young talent mobilisation. By principle, the Sustainable Innovation Zone is an open grassroots movement with strong diplomatic ties to the government and the academia (GUD, 2021). In practice, that principle leads to numerous projects and their successful implementations, frequent periodic (e.g. weekly) meetings, various workshops, conferences, seminars and popular science events and festivals. It is worth to mention some of them, carried out between 2015 and 2021:

- the project of electric car sharing for the Porto Alegre urban space;

- the project and implementation of a solar-energy powered charging stations for electric vehicles, the first such facility in the city;

- Espaço Floresta - the creation of the city's community gardening and composting centre;

- the promotion of solar energy and energetic efficiency in the ZISPOA;

- Creathon DMLU - the co-organisation of an event about the city's waste dumps;

- the organisation of Earth Day within the ZISPOA;

- the project and implementation of a solar tree;

- the project and implementation of the first streetlight fuelled by solar energy;

- the project of photovoltaic installations on all 99 of Porto Alegre's schools;

- ZISPOA Global Climate Challenge - the promotion of bikeways and bicycle parkings;

- the project of the city's first parklet.

the programme of five-year-long cooperation with the City University of New York (CUNY), under which international seminars, workshops and research were carried out. 
Tab. 1. Selected ZISPOA initiatives and the entities involved in their implementation, Source: author's own work Tab. 1. Zestawienie wybranych inicjatyw ZISPOA z podmiotami uczestniczącymi w ich realizacji, Źródło: opracowanie własne

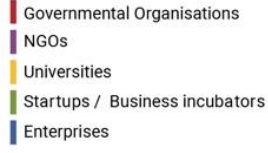

GeoSUMR - international initiative for sustainable geoinformation and geocitizen mapping
Espaço Floresta - the creation of the city's open community centre for gardening and composting
| Government of Sweden, Embassy of Sweden in B razil

| The Swedish Institute

Swedish Incubators and Science Parks

MVM Technologies

| Young Energy

| Oz Engenharia

Print Up 3D

| Orkestra

Ecotelhado

| UFRGS

BMW
| Global Urban Development

| US Government, US Depa rtment of State

| Porto Alegre Resiliente

Ecocity Builders

| AAG - American Association of Geog raphers

Ecocity Builders

| ESRI - Envi ronmental Systems Resea rch Institute

| 3 C Arquitetura e Urbanismo

|| UFRGS
I Town Hall - DM LU - City Department of Waste Management | Re-Ciclo 
2017

2017

2017

2019

2019
ZUNI Project - ZISP OA at universities
UFRGS - Uni versidade Federal do Rio Grande do Sul

PUCRS - Pontifícia Uni versidade Católica do Rio Grande do Sul

Unisinos - Uni versidade do Vale do Rio dos Sinos

UniRitter - Cent ro Universitário Ritter dos Reis

Hestia - business incuba tor (UFRGS)

I Tecnopuc - business incuba tor (PUCRS)

OTMZA

Renova

| AIESEC

$\begin{array}{ll}\begin{array}{l}\text { Promotion of bikeways } \\ \text { and bicycle parkings }\end{array} & \text { EPTC - Emp resa Pública de Transporte e circulação } \\ \text { ZISPOA Bike-Friendly Festival } & \text { | Porto Alegre City Council } \\ \text { MOVE SMART Challenge } & \text { | Pedal das Gurias } \\ \text { ZISPOA Glocal Climate Challenge } & \text { | Pedal da Inclusão } \\ & \text { | Ped Alegre } \\ & \text { | Loos - think tank } \\ & \text { | Marquise } 51 \text { Centro Criativo } \\ & \text { Vila Velo } \\ & \text { Royal Institute of Technology in Stockholm }\end{array}$

| Royal Institute of Technology in S tockholm

Promotion of solar energy

I US Consulate in Porto Alegre

and energetic efficiency

$\begin{array}{ll}\begin{array}{l}\text { Project and implementation } \\ \text { of the city's first } \\ \text { environment-friendly parklet }\end{array} & \text { | Elysia Energia SOla } \\ & \text { | Josephyna's } \\ \text { | Urban Sala Bim } \\ \text { | Mirá } \\ \text { | Solidariedade } \\ \text { Cooperativa CTSA }\end{array}$

ONU Habitat Urban Thinkers Campus Porto Alegre
| Global Urban Development

| Conselho de Arquitetura e Urbanismo do RS (C AU-RS)

UFRGS

Pacto Alegre

Associação Cultural Vila Flores

UFO Space

| Pulsar
Project of PV panel installation on all 99 state schools in Porto Alegre
| Porto Alegre Town Hall 
ZISPOA projects materialise in a specific area of the city and, consequently, affect the organisation of public space, thus impacting the behaviour of citizens and improving the quality of their life. They provoke cooperation within local, neighbourhood communities. One of such initiatives is the first fully environment-friendly parklet in Porto Alegre, equipped with PV panels that provide nighttime LED lighting and electronic devices charging. The project also included a bicycle parking. The parklet's structure was built with eco-blocks made of construction waste. The blocks themselves were manufactured by a local NGO Solidariedade, which spends the sales profit on the basic needs of povertystricken families. For so complex an idea, both the project and its implementation require various organisations to come to agreement. In this case, except for the activists belonging to the ZISPOA Bike-Friendly group, a number of NGOs and private enterprises were involved. Below is a selection of ZISPOA projects, along with the organisations involved in their implementation (Tab. 1). The aim of the above is to show the vast diversity of the entities involved in the activities and the public debate provoked by the Porto Alegre Sustainable Development Zone. The data used in this list come from the ZISPOA's official website (www.zispoa.info) and from www.globalurban.net.

The intensified actions for innovation and sustainability have an indisputable impact on the definite downtown area and the local community, but does it stand a chance to affect the general image of the city and the living comfort of its inhabitants? Since 2014 the Urban Systems company, which specialises in demographic data analysis and researching trends in cities, has been preparing the Connected Smart Cities ranking. All Brazilian cities of more than 50000 inhabitants (i.e. over 670 urban centres) are examined. Various aspects are analysed in the following categories: mobility and accessibility, environment, urban planning, technology and innovation, public health, safety, education, entrepreneurship, energy, governance and economy. The year 2015 was also the moment when the ZISPOA was established, so the results of the rankings may illustrate the emerging trends resulting from the new strategy for Porto Alegre. (Tab. 2).

Tab. 2. Connected Smart Cities ranking results for Porto Alegre city for the period 2015-2021, Source: author's own work. Tab. 2. Zestawienie wyników rankingu Connected Smart Cities dla miasta Porto Alegre w latach 2015-2021, Źródło: opracowanie własne.

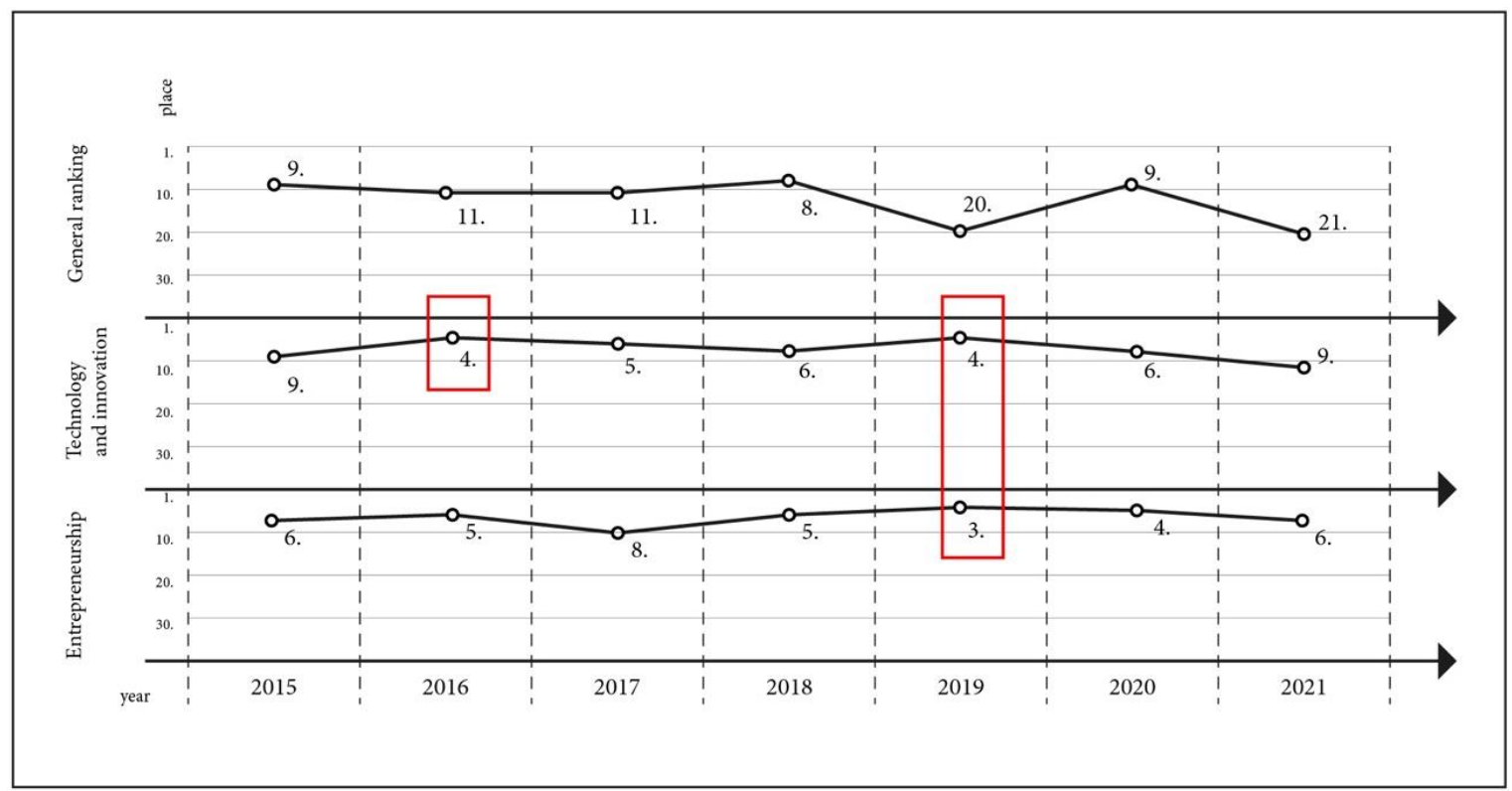


To achieve that, two categories, which are the most relevant for the operation of the SIZ have been chosen: Technology and Innovation and Entrepreneurship. Moreover, the general rankings for the years 2015-2021 have also been presented. The indicators used to evaluate technology and innovation included: the percentage of the city covered by fast broadband Internet connection, access to the Internet per the number of citizens, the number of acquired patents and research grants, the growth index for tech companies and business incubators. In the category of "entrepreneurship", on the other hand, the following are taken into account: patents and research grants, the growth index for tech companies, technology parks, the growth index for the creative industry, business incubators and the growth index for individual micro-enterprises. The data come from the Urban Systems databases: www.urbansystems.com.br (Urban Systems, 2021).

In the Technology and Innovation category Porto Alegre took the first leap in 2016 (from 9th to 4th place), and it kept its high position in subsequent years, up until 2019. In the Entrepreneurship category the city was ranked between 8th and 4th places as compared to other Brazilian cities. Taking into account both categories, Porto Alegre's best standing was in 2019. In the Entrepreneurship category, the city only yielded to such agglomerations as Rio de Janeiro and Campinas (São Paulo). Although Porto Alegre dropped dramatically in the general ranking (to 20th place) in that year, it significantly advanced in the categories connected with innovation and entrepreneurship. It is fair to say that the year 2019 was a breakthrough of a sort, because in subsequent years a downward tendency in all the categories in question is observed. That trend is very likely related to the epidemiological situation of the years 2020-2021. The pandemic caused by the SARS-CoV-2 virus has played its part in the decrease in activity in the public space-meetings, workshops and conferences, which were the catalyst of activities within the ZISPOA in the earlier years, were cancelled.

\section{POZNAŃ}

According to the data from Statistics Poland (Pol. Główny Urząd Statystyczny) from 2018 (Statistics Poland, 2021), the capital of the Greater Poland region has just over 530000 inhabitants, and the city limits enclose an area of $262 \mathrm{~km}^{2}$ (Urząd Statystyczny w Poznaniu, 2021). The population of Poznań is $35.33 \%$ of Porto Alegre's, while its area amounts to $52.4 \%$ of that of the Brazilian city. Despite the much smaller scale, Poznań is a vibrant cultural and scientific centre with very welldeveloped business. In the Globalization and World Cities Research Network international ranking of cities prepared by British Loughborough University, in 2020 Poznań was ranked in the "Gamma " group, leaving behind Porto Alegre, which is classified in the High Sufficiency category of the ranking (The World According to GaWC, 2020). The GaWC ranking assesses mutual relations between cities from around the world by examining their international networking and advanced business services. Poznań is also a very important academic centre. In the academic year of 2018/2019, the capital of Greater Poland had over 104,000 students, which gives 194 students per 1,000 inhabitants - the highest ratio in Poland (Badam, 2021). Such a large amount of intellectual capital must have a bearing on this urban centre's potential. The report on the state of the city in 2020 prepared by the City Council states that Innovation plays an increasingly important role in the economy of Poznan, incl. strong startups environment and the games industry, cooperation platforms and networks supporting the development of clustering and high-tech. In 2020, there was registered a number of 10.7 thousand companies in Poznań from the creative sectors (...) there were over 200 start-ups, operating mainly in the sector of new technologies with the use of artificial intelligence, Internet of Things and big data. According to the StartupBlink Ecosystem Report 2020 Poznań is in the TOP200 group of cities in the world with the greatest start-up potential, ranking 170th among 1000 cities included in the report. (Badam, 2021). There are numerous scientific institutions operating in the field of innovation: Poznań Science and Technology Park (PSTP), Wielkopolska Centre for Advanced Technologies (WCAT), Poznań Technology and Industry Park (PTIP), NanoBioMedical Centre and Poznań Supercomputing and Networking Centre (PSNC), to name just a few. The above institutions have been marked on the diagram (Figure 4) within the city limits of Poznań. It is clear that their location is diverse, with some being situated in the vicinity of the city centre and others - within university campuses, such as the Morasko Campus (Adam Mickiewicz University) or the Warta Campus (Poznań University of Technology). Therefore, they do not compose a common, spatially uniform area. 


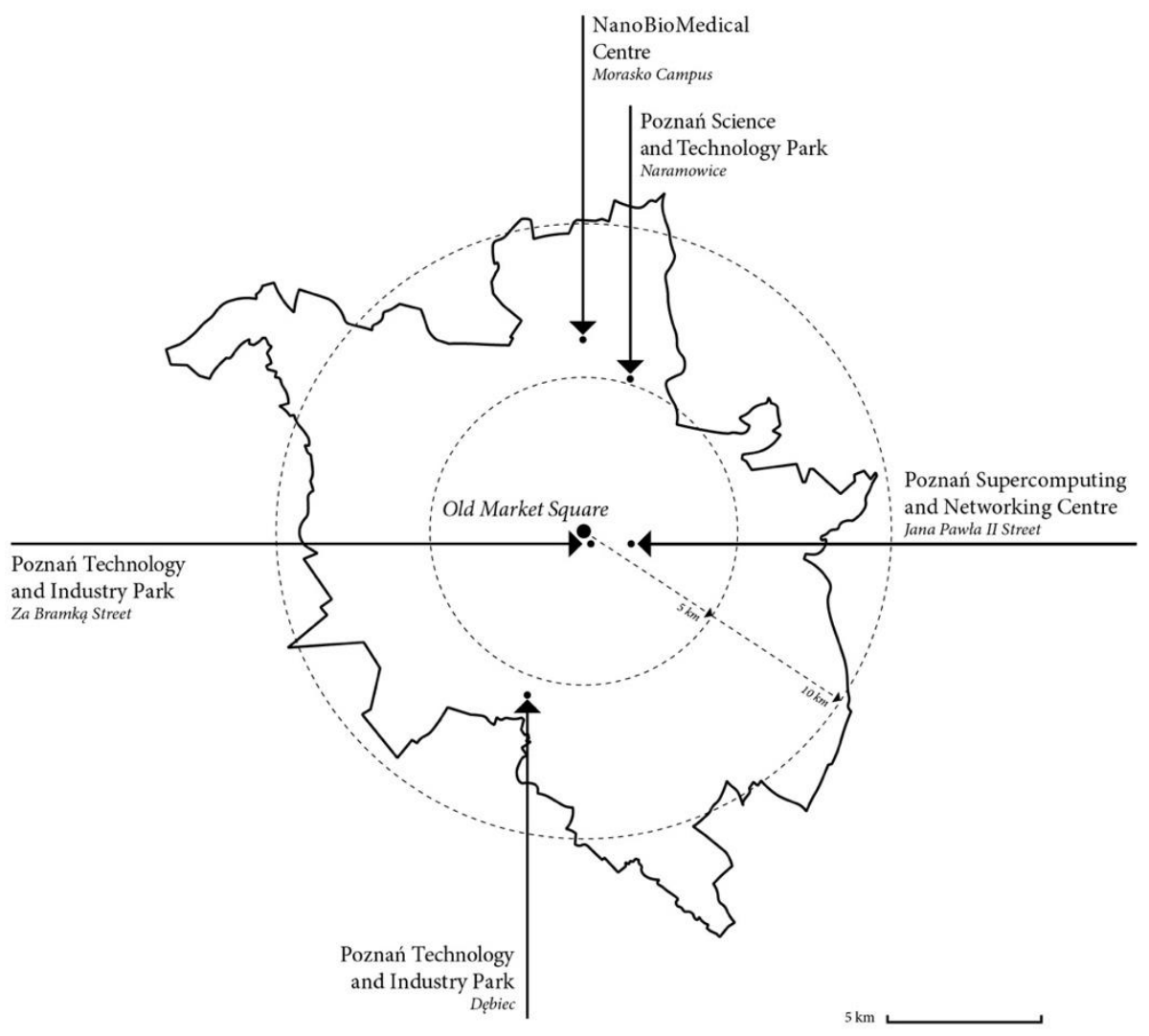

Fig. 4. Diagram presenting the locations of the institutions founded for innovation within the limits of the city of Poznań, Source: author's own work.

Ryc. 4. Schemat lokalizacji instytucji dedykowanych innowacjom w granicach miasta Poznania, Źródło: opracowanie własne.

\section{DISCUSSION}

Poznań aspires to be the leader in innovation, sustainability and social participation. The Smart City Poznań initiative by the Town Hall, with a supporting mobile application under the same name, may prove those aspirations. The city's official website states that Smart City Poznan is a dynamic and future-oriented city deeply rooted in the activities of its conscious and creative residents who can decide for themselves (Smart City Poznań, 2021). Public participation is the main axis of the Smart City Poznań idea. The following are important for the initiative: quality of life, economy, environment, community, mobility and digital city. At the same time, the projects implemented under that idea should be innovative, inclusive, integrating and utilising technological means. The mobile app allows residents to easily and quickly submit an idea for improvement in the city or notify about a problem 
while having access to the tickets submitted by other users. Another project that deserves a mention due to its country-wide uniqueness is the 3D model of Poznań, which was completed in 2018 (with later updates). The model is used to facilitate spatial planning and environmental protection, and is a useful tool for public consultations. Participatory budgeting based on the Porto Alegre model was introduced in 2013 and has successfully been used ever since (Kalisiak-Mędelska, 2016,pp. 112113). Do the above activities actually classify Poznan as a smart city? Do the residents really benefit from the initiatives for improving their living conditions? It is worth asking at this point about the definition of a smart city. Ewa Łaźniewska, the author of The essence of the concept of a smart city. The activity of the city of Poznań leading to a smart city asked the same question. The researcher analysed various definitions of the term and extracted their common denominators, such as: the occurrence of innovative processes, utilisation of knowledge (technological knowledge in particular), smart sustainability, focus on competitiveness and substantial significance of human capital (Łażniewska, 2020, pp. 109-112). All the listed qualities are fulfilled in the development strategies of both Porto Alegre (ZISPOA) and Smart City Poznań. One of the features the author of the aforementioned publication specifies is the lack of limitation to particular territories (Łaźniewska, 2020, p.109). In the face of the above, the Sustainable Innovation Zone of Porto Alegre stands out as a novelty, which is worth a closer examination. In the quoted article Łaźniewska sums up her research carried out on 2,000 Poznań students by stating i.a. the following: An important factor stimulating the transformation towards the development of smart cities is the learning process, which should be stimulated by cities with various activities informing about new technological solutions and engaging the city communities in those processes. As the author's own research indicates, young people's knowledge about that is poorly developed (Łaźniewska, 2020, p. 115). As the example of Porto Alegre shows, the gap between the efforts of city authorities and activists on the one hand and the actual involvement of residents on the other in creating cities of the future may be bridged by a Sustainable Innovation Zone. The ZISPOA is a zone in which the principles of a smart city of the future materialise intensively. There, the ideas of sustainability and innovation have been given clearly-defined spatial and time frames, and the zone itself has been defined by its name, own brand and visual identity, which makes it recognisable and almost tangible in the city space. According to Boyd Cohen-a researcher of smart city-related questions-there are three generations of smart cities (Alves, Dias i Seixas, 2019, p. 3), with the third generation engaging not only tech companies and city authorities like the first two generations, but also residents, who get involved in various initiatives. Porto Alegre is unique because it has limited, or rather assigned a specific territory. However, the zoning is not supposed to have a negative impact on the outside area - the boundaries are to intensify and materialise activities, which should be visible and recognisable in the urban space. The SIZ is a lab for a smart city in the urban tissue, a melting pot of the virtual world and innovative technologies on the one hand and the fabric of the city-its streets, pavements, buildings and, last but not least, residentson the other. Therefore, based on the existing definition of smart city, the author proposes a new one, updated with the Porto Alegre experience:

\begin{abstract}
A smart city is an area populated by aware, creative and involved residents, who cooperate for sustainable development, with the aim to improve the quality of life and quickly solve emerging problems in innovative ways. A smart city invests in its residents' intellectual capital, the development of advanced technologies and its attractiveness, thus bringing in new creative people. Its residents' initiatives are implemented in the public space, in which the virtual world and advanced technologies meet the fabric of the city, and are visible and legible to the residents.
\end{abstract}

A specified zone of sustainable innovation in a city is a challenge and an invitation for urban planners, architects, product designers, graphic designers and other creative professions to have their say in the discussion on the cities of the future. Those voices should be appropriately thought-through as early as at the design phase. An excellent example of such practices would be the Innovativeness course included in the curriculum of Architecture in the Poznań University of Technology. 


\section{CONCLUSIONS}

As a summary, a table has been created (Tab. 3) to compare the idea of the Porto Alegre Sustainable Innovation Zone with the Smart City Poznan initiative. The aim of the table is not to valuate but merely to summarise the observations included in the article.

The Porto Alegre Sustainable Development Zone is a project that consolidates the idea of an innovative and sustainable city of the future. Its time frame has been determined for the years 20152030. It is currently underway but some positive effects of the initiative can already be observed. The ZISPOA actively engages the academia, governmental and non-governmental organisations, large enterprises and creative and innovative startups. The SIZ is an open grassroots social movement with strong diplomatic ties to the government and the academia. The projects connected with the zone are carried out on a very large scale in terms of both the number of people involved and the international nature of those initiatives. They materialise in the designated area in the urban space, which is why they are so easily noticeable and bring benefits so quickly. They provoke cooperation within local, neighbourhood communities. Placing the idea of sustainable innovation in an existing, actual spatial context involves urban planners, architects and other designers, whose voice should be material in the discussion on the cities of the future. A SIZ may serve as an experiment and the model implementation of sustainability strategy in a given urban centre. Poznań also works towards acquiring the status of smart city by implementing numerous initiatives, such as the Smart City Poznań programme, investing in startups and innovations, developing technology parks and business incubators. What the capital of Greater Poland lacks is a clearly-defined zone that would serve as tangible proof of those activities, or a sustainable innovation laboratory established in a particular time and space. Another thing that is missing is a broad-scale project that would involve the academia. Provoking a movement similar to that of the ZISPOA in Poznań-a city of such large intellectual capital-and defining spatial and time frames for that initiative might be a chance for the capital of Greater Poland to become the leader of sustainable innovation on a European or even global scale.

Table 3. The summary of the research: the comparison of the ZISPOA and Smart City Poznań, including general data for the two cities and their position in the GaWC ranking for the years covered by the research (2015-2021). Source: author's own work.

\begin{tabular}{|l|c|c|}
\hline \multicolumn{2}{|c|}{ Project data } \\
\hline Criteria & ZISPOA & Smart City Poznań \\
\hline City authorities' initiative & no $\times$ & yes $\checkmark$ \\
\hline Governmental organisations' involvement & yes $\checkmark$ & yes $\checkmark$ \\
\hline NGOs' involvement & yes $\checkmark$ & yes $\checkmark$ \\
\hline Academia's involvement & yes $\checkmark$ & no $\times$ \\
\hline Enterprises' involvement & yes $\checkmark$ & yes $\checkmark$ \\
\hline Support for startups & yes $\checkmark$ & yes $\checkmark$ \\
\hline Implementation of participatory budgeting & yes $\checkmark$ & yes $\checkmark$ \\
\hline Designated area in the city & yes $\checkmark$ & no $\times$ \\
\hline Informational website & yes $\checkmark$ & yes $\checkmark$ \\
\hline Mobile application & no $\times$ & yes $\checkmark$ \\
\hline
\end{tabular}




\begin{tabular}{|l|c|c|}
\hline \multicolumn{3}{|c|}{ City general data } \\
\hline Criteria & Porto Alegre & Poznań \\
\hline University city & yes $\checkmark$ & yes $\checkmark$ \\
\hline Capital of the region & yes $\checkmark$ & yes $\checkmark$ \\
\hline City area (within administrative boundaries) & $500 \mathrm{~km}^{2}$ & $262 \mathrm{~km}^{2}$ \\
\hline Population & $1,492,351$ & 530,000 \\
\hline Position in the GaWC* ranking in 2016 & High Sufficiency & High Sufficiency \\
\hline Position in the GaWC* ranking in 2018 & High Sufficiency & Gamma - \\
\hline Position in the GaWC* ranking in 2020 & High Sufficiency & Gamma - \\
\hline
\end{tabular}

\section{OBSZAR ZRÓWNOWAŻONEJ INNOWACJI PORTO ALEGRE - STRATEGIA ROZWOJU SMART CITY NA PRZYKŁADZIE BRAZYLIJSKIEGO MIASTA W ODNIESIENIU DO POZNANIA}

\section{WSTĘP}

Zrównoważony rozwój i innowacja to dwa trendy, które definiują teraźniejszość i przyszłość miast XXI wieku. Organizacja życia w ośrodkach miejskich ma niezaprzeczalny wpływ na środowisko naturalne i globalne procesy klimatyczne. Przewiduje się, że megamiasta są przyszłością cywilizacji, powinniśmy je zatem postrzegać jako szanse, a nie zagrożenie. To one powinny być zieloną przyszłością planety. W takim przypadku zrównoważony rozwój staje się pilną potrzebą w rozwiązywaniu problemów miast, bo to właśnie ośrodki miejskie zużywają największe światowe zasoby i generuja najdotkliwsze marnotrawstwo (Leite, 2012, s. 14). Zrównoważony rozwój w połączeniu z innowacyjną technologią oraz wielopłaszczyznowym zaangażowaniem świadomego społeczeństwa mogą stać się skutecznym narzędziem w budowaniu inteligentnych miast przyszłości. W artykule zaprezentowano międzynarodowy projekt powołany do życia w brazylijskiej stolicy stanu Rio Grande do Sul Porto Alegre. Powstały tam w 2015 roku Obszar zrównoważonej innowacji (OZI) wdraża założenia strategii Leapfrog, a jego celem jest przemiana Porto Alegre w miasto najbardziej innowacyjne i zrównoważone w Ameryce Łacińskiej do 2030 roku. W artykule przeanalizowano główne cele i założenia ZISPOA, projekty oraz zaangażowane w ich realizację podmioty. Porównano Obszar Zrównoważonej Innowacji Porto Alegre z inicjatywą Smart City Poznań, a także zaproponowano nową definicję określenia smart city. 


\section{MATERIAŁY I METODY BADAWCZE}

Celem artykułu jest weryfikacja działań społecznych mających miejsce w przestrzeni miasta Porto Alegre w ramach ZISPOA w latach 2015-2021, a także analiza charakteru podmiotów zaangażowanych do ich realizacji. Postawiono sobie za cel sprawdzenie czy inicjatywy podjęte przez ZISPOA realnie angażują różne grupy społeczne w tym mieście i w jaki sposób są odbierane przez lokalne środowisko. Kolejnym etapem badań było porównanie doświadczeń brazylijskiego miasta z podobnymi inicjatywami podejmowanymi w stolicy Wielkopolski, w tym samym okresie czasu.

Metoda badawcza polegała na przeprowadzeniu kwerendy bibliograficznej i obserwacji inicjatyw realizowanych w ramach OZI za pomocą portali internetowych - włączając $w$ to oficjalne serwisy informacyjne ZISPOA, Global Urban Development, relacje miedialne oraz konta społecznościowe ZISPOA, a także startupów ( $m$. in.: Elysia Energia Solar, Oz Engenharia, Point, Young Energy, MVM Technologies, Ecotelhado), organizacji pozarządowych (m. in.: Acossiação Cultural Vila Flores, Mobicidade, Pedal das Gurías, Solidariedade, Pacto Alegre), przedsiębiorstw (m.in.: 3C Arquitetura e Urbanismo, Loop, Marquise 51 Centro Criativo, Pulsar). Podmioty uczestniczące w projektach ZlSPOA zostały usystematyzowane i przyporządkowane następującym kategoriom: organizacja rządowa, organizacja pozarządowa, uczelnia wyższa, startup/inkubator przedsiębiorczości, przedsiębiorstwo. Dzięki relacjom rozmaitych uczestników inicjatyw, uzupełnionych medialnymi doniesieniami, autorka projektu badawczego mogła zapoznać się z różnymi głosami i zrozumieć jak projekty ZISPOA są postrzegane w lokalnym środowisku. Do realnej oceny wpływu OZI na funkcjonowanie miasta nie wystarczyło jedynie sprawozdanie z wykonanych projektów. Autorka sięgnęła po rankingi Connected Smart Cities, oceniające wszystkie miasta brazylijskie w różnych kategoriach w latach 2015-2021. Do własnej analizy wybrała kategorie odpowiadające celom ZISPOA: „technologia i innowacja”, „przedsiębiorczość” oraz ogólne miejsce w rankingu. W ten sposób udało się zaobserwować trendy w ocenie miasta na przestrzeni ostatnich sześciu lat. Należy wspomnieć, że miasto Porto Alegre nie jest autorce obce - przed rokiem 2019 miała ona okazję kilkukrotnie wizytować to miasto, w tym strefę ZISPOA. Niestety sytuacja sanitarno-epidemiologiczna w latach 2020-21 nie pozwoliła na rewizytę i weryfikację efektów tej działalności in situ. Niemniej ogólne wnioski są oparte nie tylko na wspomnianej kwerendzie, ale również na osobistym doświadczeniu sprzed okresu pandemii.

Kolejnym zadaniem, którego podjęła się autorka była próba porównania eksperymentu Porto Alegre $z$ Poznaniem, w tym celu powstały dwa rysunki - schematy przedstawiające granice administracyjne obu miast, a w ich obrębie zostały zaznaczone, w przypadku Poznania: instytucje związane z rozwojem przedsiębiorczości i innowacji, a w przypadku ZISPOA - obszar objęty projektem oraz strategiczne miejsca, m.in. takie jak: kampusy uniwersyteckie, parki, targi żywności, szpitale, kościoły, teatry znajdujące się $w$ jego zakresie. Autorka wyszczególniła również poznańskie inicjatywy związane z aspiracjami miasta do osiągnięcia statusu smart city, $\mathrm{m}$. in. model miasta 3D, program oraz aplikację Smar City Poznań, budżet partycypacyjny oraz inne działania, które można porównać z ZISPOA. W przypadku Poznania przeanalizowano również pozycję maista w międzynarodowym rankingu Globalization and World Cities Research Network oraz Raport o stanie Miasta Poznania za 2020 rok przygotowany przez Radę Miasta. Osobiste doświadczenia i obserwacje tego ośrodka miejskiego wynikają z miejsca zamieszkania autorki artykułu.

\section{PORTO ALEGRE}

Porto Alegre to ośrodek miejski liczący niemal 1,5 miliona mieszkańców, obejmujący obszar $500 \mathrm{~km}^{2}$ (IBGE, 2021), położony nad malowniczym jeziorem Guaíba, dominującym w krajobrazie miasta, które wraz z jeziorem Lagoa dos Patos tworzą największą w Ameryce Południowej, żeglowną lagunę. Stanowi istotny węzeł komunikacyjny w regionie, posiada międzynarodowe lotnisko Aeroporto Salgado Filho. Jest ważnym ośrodkiem handlu, przemysłu, kultury i edukacji. Miasto założone w 1809 roku stanowi centrum kultury gaúcho (gaúcho - południowoamerykański pasterz bydła, pracujący na pampach Argentyny, Urugwaju, Paragwaju, Chile i południowej Brazylii. Potocznie mieszkaniec stanu Rio Grande do Sul). Jest siedzibą kilku uniwersytetów, z których wiodącą pozycję zajmuje federalny uniwersytet UFRGS. Porto Alegre zaistniało na arenie międzynarodowej w latach 90-tych XX wieku z racji pionierskiego przeprowadzenia procesu budżetu obywatelskiego. Początki 
tego mechanizmu demokracji partycypacyjnej miały miejsce w innym mieście stanu Rio Grande do Sul - Pelotas, gdzie w roku 1983 ówczesny burmistrz Bernardo de Souza wcielił w życie program pod hasłem: Cała moc emanuje z ludu, który to de facto był prekursorem idei budżetu obywatelskiego. Program zakładał możliwość uczestnictwa mieszkańców w dyskusji i podejmowaniu decyzji odnoszących się do spraw lokalnych, szczególnie w kwestiach edukacyjnych (Streck, Pitano i Moretti, 2017, s.13). Po odniesionym sukcesie pomysł ten został powielony i ustrukturyzowany w stolicy stanu - Porto Alegre, aby następnie zyskać status prawa stanowego pod nazwą budżetu partycypacyjnego (port. orçamento participativo). Nowatorskie rozwiązanie zyskało rozgłos na całym świecie, a podobne inicjatywy pojawiły się w wielu miastach Europy, Azji, Afryki, czy w Ameryce Północnej.

Porto Alegre można uznać największym w świecie poligonem doświadczalnym demokracji bezpośredniej o międzynarodowym znaczeniu, czego potwierdzeniem jest uznanie tej formy lokalnego zarządzania jako wzorzec do naśladowania na Konferencji ONZ Habitat II w 1996 r. w Stambule (Kuriata, 2013, s.41). Również w Polsce niektóre miasta zainteresowały się tym rozwiązaniem i począwszy od Sopotu (od 2011r.) budżet partycypacyjny staje się coraz popularniejszym narzędziem bezpośredniej demokracji w kolejnych polskich miastach. Jest to wyraźny przykład tego, że lokalnie wypracowane doświadczenia mogą mieć wpływ na organizację życia w miastach w skali globalnej.

O tym, że stolica Rio Grande do Sul ma niebagatelny wpływ na wizję miast przyszłości może świadczyć również organizacja międzynarodowego wydarzenia o znaczeniu globalnym - Światowe Forum Społeczne (ang. World Social Forum) pod hasłem: Inny świat jest możliwy. W latach 2001-2003 w Porto Alegre odbyły się trzy pierwsze edycje tego wydarzenia, które zgromadziły setki tysięcy uczestników z całego świata. W pierwszej dekadzie XXI wieku wydarzenie to było uważane za przeciwwagę dla Światowego Forum Ekonomicznego w Davos (Wiechetek, 2020, s.26), a Le Monde Diplomatique obwieszczało tezę, że nowy XXI wiek właśnie rozpoczął się w Porto Alegre. Nieprzypadkowo właśnie w tym miejscu, na gruncie powyższych doświadczeń, w 2015 roku została powołana nowa inicjatywa pod nazwą: Obszar Zrównoważonej Innowacji Porto Alegre (ZISPOA). Organizacja Global Urban Development, przy wsparciu finansowym Banku Światowego, rozpoczęła w ten sposób prace nad wdrażaniem strategii ekonomicznej Leapfrog. Jest to termin, który początkowo odnosił się do ekonomii innowacji i był łączony z ideą skoku technologicznego firm. W ostatnim czasie koncepcja ta jest wykorzystywana w teorii rozwoju zrównoważonego. Wskazuje ona na kraje rozwijające się, które mogą porzucić stare technologie i „skoczyć w przód” (ang. leapfrog) omijając rozwiązania przyjęte przez kraje zaawansowane w przeszłości. Zamiast wdrażania struktur produkcji opartych na intensywnym zużyciu nieodnawialnych zasobów naturalnych, kraje rozwijające się mogą już teraz zainwestować w produkcję opartą na odnawialnych źródłach energii, takich jak energia słoneczna, wiatrowa czy wodna (Scatolin, Misael, 2011, s.7). Marc Weiss, dyrektor generalny Global Urban Development, rozpoczął współpracę z miastem Porto Alegre w 2011 roku, kiedy to Brazylijska Agencja Rozwoju Przemysłu (ABDI) wraz z Unią Przemysłową Stanu Rio Grande do Sul zwróciły się do niego o pomoc w opracowaniu strategii rozwoju dla miasta i stanu (Weiss, Sedmak-Weiss, Rodriguez, 2021). W późniejszych latach współpracował z lokalnymi organizacjami i uniwersytetami realizując inwestycje Banku Światowego wspierające rozwój strategii rozwoju ekonomicznego Rio Grande do Sul. Na kanwie tej współpracy i wymiany doświadczeń powstał pierwszy w Ameryce Południowej Obszar Zrównoważonej Innnowacji ZISPOA. Następnie ideę tę powtórzono w innym brazylijskim mieście - Santo Ângelo (ZISSAN), w mieście Panamá w Panamie (ACTA), w Londynie, Nowym Jorku (ZISs - Brooklyn) i w Western Sydney, w Australii. Główną ideą Obszaru Zrównoważonej Innowacji jest stworzenie skoncentrowanego modelu zrównoważonego rozwoju i innowacji, jako procesu konsolidacji miasta, w którym cenione są relacje międzyludzkie, a problemy rozwiązuje się w inteligentny sposób. Ruch Obszarów Zrównoważonej Innowacji, koordynowany przez Global Urban Development, zgromadził już ponad 700 liderów i specjalistów w 60 krajach na świecie.

\section{ZISPOA}

ZISPOA (Obszar Zrównoważonej Innowacji Porto Alegre) stanowi pierwszy ważny etap wdrażania Strategii Gospodarczej Leapfrog Banku Światowego dla miasta i stanu Rio Grande do Sul. W 2015 roku wyznaczono obszar w śródmieściu, obejmujący częściowo dwie dzielnice: Independência i Floresta (rys. 3). Wybranie tej lokalizacji było związane z bliskością kampusów uniwersyteckich, parków 
technologicznych, inkubatorów przedsiębiorczości, co miało służyć powstaniu efektu magnesu przyciągającego talenty i kreatywne jednostki z całego świata. Wytyczenie konkretnego obszaru w mieście miało stanowić wyraźną koncentrację eksperymentów $z$ użyciem zaawansowanych technologii służących oszczędności, ponownemu wykorzystaniu materiałów i efektywnemu korzystaniu z zasobów naturalnych. Dzięki takiemu podejściu ludzie mają osiągnąć dobrobyt polepszając jakość życia, zarabiając i oszczędzając więcej pieniędzy, mając lepsze miejsce pracy, jednocześnie wypełniając założenia Porozumienia Paryskiego i Nowej Agendy Miejskiej podpisanej w Quito w 2016 r. W kolejnym etapie realizacji projektu rozszerzono jego obszar o 8 dzielnic: Azenha, Bom Fim, Centro Histórico, Cidade Baixa, Farroupilha, Rio Branco, Santa Cecília i Santana (rys. 3). W granicach ZISPOA znalazły się m. in.: największy park miejski, dwa federalne uniwersytety i trzy inne uczelnie wyższe, sześć szpitali, najstarszy i największy brazylijski targ żywności organicznej, cztery duże prywatne firmy oraz liczne instytucje edukacyjne, kulturalne i religijne. ZISPOA od początku ściśle współpracuje z wykładowcami i studentami UFRGS, pracując nad tym, aby uniwersytet stał się światowym liderem innowacji do $2030 \mathrm{r}$. W roku 2017 Rada Miasta jednogłośnie zagłosowała za oficjalnym ustanowieniem Obszaru Zrównoważonej Innowacji wraz z jej granicami i rozpoczęła aktywną współpracę na rzecz włączenia ZISPOA do miejskiego planu zagospodarowania przestrzennego (ZISPOA Info, 2021).

Obszar Zrównoważonej Innowacji opiera się na sześciu kluczowych zagadnieniach:

- Innowacja i technologia;

- Przedsiębiorczość i startupy;

- Zrównoważony rozwój i efektywne gospodarowanie zasobami;

- Kreatywność i współpraca;

- Partycypacyjne zarządzanie społeczne;

- Środowisko przyjazne biznesowi.

Celem ZISPOA jest transformacja Obszaru Zrównoważonej Innowacji w strefę najlepiej zasilaną energią słoneczną w Ameryce Południowej, najbardziej energooszczędną, najlepiej skomunikowaną cyfrowo, przyjazną technologiom opartym na energii odnawialnej i przyjazną rowerom. Istotnym obszarem działania jest edukacja i zaangażowanie środowiska akademickiego, w tym kwestie związane z nauczaniem idei zrównoważonego rozwoju. Wprowadzanie odpowiednich przedmiotów w program nauczania studiów gwarantuje absolwentom wejście na rynek pracy z odpowiednim przygotowaniem. Zdaniem Valérii Café, dyrektor badań Brazylijskiego Związku Specjalistów ds. Zrównoważonego Rozwoju: Osoby wykształcone w kierunku zrównoważonego rozwoju są aktualnie postrzegane jako strategiczne w czasach kryzysu wodnego i energetycznego. Wyróżniają się, ponieważ mogą wskazać drogę firmom w jaki sposób obniżyć koszty (Gentil, 2018, s.39). Celem programu ZISPOA jest również zapewnienie wzrostu startupom, młodym przedsiębiorstwom uniwersyteckim, technikom, studentom i aktywistom. Nowe pokolenie, dzięki swojej energii i kreatywności ma szansę zmienić przestrzeń miejską w inteligentne miasta przyszłości. Szacuje się, że w ZISPOA większość osób pracujących jest młoda - około $42 \%$ to osoby w wieku do 35 roku życia, z różnym wykształceniem, w większości wyższym, głównie absolwenci kierunków takich jak: Administracja, Inżynieria i Zarządzanie Środowiskiem (Gentil, 2018, s. 39). Jedną z większych inicjatyw angażujących środowisko akademickie jest ZISProf - projekt, w którym uczestniczy, w charakterze doradców naukowych, ponad 150 nauczycieli akademickich z 16 uczelni. Pracownicy naukowi oferują swoim studentom pomoc w przygotowaniu projektów i badań naukowych realizowanych na terenie Obszaru Zrównoważonej Innowacji.

Zdaniem dyrektora generalnego GUD Marca Weissa, projekty ZISPOA generują trendy w przestrzeni miejskiej, takie jak: powszechnie użycie technologii do innowacji, silne poczucie celu, jakim jest zrównoważony rozwój, dążenie do wprowadzania zmian, niewielkie zmiany przynoszące szybkie i widoczne korzyści (agile delivery / quick wins) czy mobilizacja młodych talentów. OZI w swoim założeniu to oddolny $\mathrm{i}$ otwarty ruch, ale $z$ silnym powiązaniem dyplomatycznym z rządem i środowiskiem akademickim (GUD, 2021). Założenia te realizują się w postaci licznych projektów zwieńczonych udanymi realizacjami, cyklicznych, częstych (np. cotygodniowych) spotkań, różnego rodzaju warsztatów, konferencji, seminariów, a także wydarzeń popularno-naukowych i festiwali. Warto wspomnieć o kilku z nich, realizowanych w latach 2015-2021: 
- Projekt programu współdzielenia pojazdów elektrycznych dla przestrzeni miejskiej Porto Alegre;

- Projekt i realizacja pierwszej w mieście stacji ładowania pojazdów elektrycznych, zasilanej energią słoneczną;

- Espaço Floresta - powstanie miejskiego, społecznego centrum ogrodnictwa i kompostowania;

- Promocja energii słonecznej i efektywności energetycznej w ZISPOA;

- Creathon DMLU - współorganizacja wydarzenia poświęconego miejskim wysypiskom śmieci;

- Organizacja Światowego Dnia Ziemi w ramach ZISPOA;

- Projekt i realizacja drzewa solarnego;

- Projekt i realizacja pierwszej lampy ulicznej zasilanej energią solarną;

- Projekt instalacji paneli fotowoltaicznych na wszystkich 99 szkołach publicznych w Porto Alegre;

- ZISPOA Global Climate Challange - promocja dróg rowerowych i miejsc postojowych dla rowerów;

- Projekt pierwszego w mieście parkletu;

- Program 5-petniej współpracy z Uniwersytetem Miasta Nowy York (CUNY) w ramach której zorganizowano międzynarodowe seminaria, warsztaty i badania;

Projekty ZISPOA materializują się w określonym obszarze w mieście i dzięki temu mają również wpływ na organizację przestrzeni publicznych, a co za tym idzie - na zachowania mieszkańców i poprawę jakości ich życia. Prowokują współpracę w ramach lokalnych, sąsiedzkich społeczności. Jedną z inicjatyw tego typu jest pierwszy w Porto Alegre w stu procentach ekologiczny parklet. Wyposażony w panele fotowoltaiczne, które zapewniają nocne oświetlenie LED oraz ładownie urządzeń elektronicznych, w projekcie znalazło się również miejsce postojowe dla rowerów. Konstrukcja parkletu jest wykonana z eko-bloczków pochodzących z gruzu budowlanego, wyprodukowanych przez lokalną organizację pozarządową Solidariedade, która dochód ze sprzedaży przeznacza na podstawowe środki do życia dla ubogich rodzin. Na projekt, jak i realizację tak złożonego pomysłu potrzebne jest porozumienie różnych organizacji, w tym przypadku oprócz aktywistów z grupy ZISPOA Bikefriendly zaangażowano organizacje pozarządowe i prywatne przedsiębiorstwa. Poniżej zaprezentowano wybrane projekty ZISPOA oraz organizacje zaangażowane w ich realizacje (Tab.1).

Celem tego zestawienia jest wskazanie na bogatą różnorodność podmiotów uczestniczących w aktywnościach oraz publicznej debacie wywołanej przez Obszar Zrównoważonej Innowacji Porto Alegre. Dane wykorzystane w tym zestawieniu pochodzą z oficjalnej strony ZISPOA www.zispoa.info oraz ze strony www.globalurban.net

Intensyfikacja działań zwróconych w stronę innowacji i zrównoważonego rozwoju ma niewątpliwy wpływ na wyznaczony obszar w śródmieściu i lokalną społeczność, ale czy ma szansę wpłynąć na ogólny wizerunek miasta i komfort życia jego mieszkańców? Firma Urban Systems, specjalizująca się $w$ analizie danych demograficznych i badaniu trendów w miastach, od 2015 roku prowadzi ranking Connected Smart Cities. Badaniu poddawane są wszystkie miasta brazylijskie powyżej 50 tys. mieszkańców (co stanowi liczbę ponad 670 ośrodków miejskich). Analizuje się różne aspekty w następujących kategoriach: mobilność i dostępność, środowisko, urbanistyka, technologia i innowacja, zdrowie publiczne, bezpieczeństwo, edukacja, przedsiębiorczość, energia, zarządzanie i ekonomia. Rok 2015 to także rok powołania ZISPOA, zatem zestawienie wyników kolejnych rankingów może zobrazować pojawiające się tendencje wywołane nową strategią dla Porto Alegre. W tym celu wybrano dwie kategorie, które najlepiej wpisują się w obszar działania ZIS: „technologia i innowacja” oraz „przedsiębiorczość”. Zaprezentowano także wyniki ogólne rankingu uzyskane w kolejnych latach 2015-2021. Wskaźniki wykorzystywane do badania technologii i innowacji to m.in: procent pokrycia miasta szybkim łączem szerokopasmowym, dostęp do sieci internetowej w przeliczeniu na liczbę mieszkańców, ilość zdobytych patentów i grantów naukowych, wskaźnik wzrostu firm technologicznych, inkubatorów przedsiębiorczości. Natomiast w kategorii „przedsiębiorczość” badane są: patenty i granty naukowe, wskaźnik wzrostu firm technologicznych, parki technologiczne, wskaźnik wzrostu przemysłu kreatywnego, inkubatory przedsiębiorczości oraz wskaźnik wzrostu mikro firm indywidualnych. Dane pochodzą z baz danych Urban Systems: www.urbansystems.com.br (Urban Systems, 2021). 
W roku 2016 można zaobserwować pierwszy skok z 9. na 4. miejsce w rankingu, w kategorii „technologia i innowacja”, w kolejnych latach do 2019 roku pozycja miasta w tej kategorii utrzymywała się również wysoko. „Przedsiębiorczość” w porównaniu z innymi brazylijskimi miastami oscylowała między 8 a 3 miejscem. Biorąc pod uwagę obie kategorie równocześnie można zaobserwować, iż najlepsze wyniki zostały odnotowane w roku 2019. W kategorii „przedsiębiorczość” Porto Alegre ustąpiło miejsca jedynie takim miastom jak: Rio de Janeiro i Campinas (São Paulo). Mimo tego, że miasto odnotowało w tym samym roku znaczny spadek w rankingu ogólnym (miejsce 20.), kategorie związane z innowacją i przedsiębiorczością zdecydowanie wysunęły się na prowadzenie. Można powiedzieć, że rok 2019 był swego rodzaju przełomowym, ponieważ w kolejnych latach obserwuje się tendencję spadkową we wszystkich omawianych kategoriach. $Z$ dużym prawdopodobieństwem trend ten można powiązać z sytuacją sanitarno-epidemiologiczną w latach 2020-21. Pandemia wywołana wirusem SARS-CoV-2 przyczyniła się do gwałtownego zmniejszenia aktywności w przestrzeni publicznej, zaprzestano organizowania spotkań, warsztatów i konferencji, które były we wcześniejszych latach katalizatorem działań w obrębie ZISPOA.

\section{POZNAŃ}

Stolica Wielkopolski, wg danych statystycznych GUS z 2018 roku (GUS, 2021), liczy sobie nieco ponad 530 tys. mieszkańców, a granice miasta wydzielają teren o powierzchni $262 \mathrm{~km}^{2}$ (Urząd Statystyczny w Poznaniu, 2021). W porównaniu z Porto Alegre liczba mieszkańców Poznania stanowi $35,33 \%$ populacji brazylijskiego miasta i $52,4 \%$ jego powierzchni. Pomimo dużo mniejszej skali Poznań jest prężnie działającym ośrodkiem kultury i nauki, a także bardzo dobrze rozwiniętym ośrodkiem biznesu. W międzynarodowym rankingu miast Globalization and World Cities Research $\mathrm{Ne}$ twork, przeprowadzanym przez brytyjski Loughborough University, w roku 2020 Poznań uplasował się w grupie "Gamma -" wyprzedzając tym samym Porto Alegre, które we wspomnianym zestawieniu występuje w niższej kategorii high sufficiency (The World According to GaWC, 2021). Ranking GaWC ocenia wzajemne relacje między miastami z całego świata badając ich międzynarodowe usieciowienie i zaawansowane usługi biznesowe. Poznań jest także bardzo ważnym ośrodkiem akademickim. W roku 2018/2019 w stolicy Wielkopolski studiowało ponad 104 tys. osób, a liczba studentów na każde 1000 osób wyniosła 194 - jest to najwyższy wskaźnik w Polsce (Badam, 2021). Tak duży kapitał intelektualny siłą rzeczy ma przełożenie na potencjał tego ośrodka miejskiego. W raporcie o stanie miasta za rok 2020 przygotowanym przez Radę Miasta czytamy: W gospodarce Poznania coraz większą rolę odgrywa innowacyjność, w tym silne środowisko startupów oraz przemysł gier, platformy i sieci współpracy wspierające rozwój klasteringu i high-tech. W 2020 r. w Poznaniu było zarejestrowanych 10,7 tys. firm sektorów kreatywnych (...) funkcjonowało ponad 200 startupów, działających przede wszystkim w sektorze nowych technologii z wykorzystaniem sztucznej inteligencji, Internetu rzeczy i big data. Według StartupBlink Ecostystem Report 2020 Poznań jest w grupie TOP200 miast na świecie posiadających największy potencjał startupowy, zajmując 170. pozycje wśród 1000 miast ujętych w raporcie (Badam, 2021). W mieście funkcjonuje wiele instytucji naukowych działających w obszarze innowacji, można do nich zaliczyć m. in.: Poznański Park NaukowoTechnologiczny (PPNT), Wielkopolskie Centrum Zaawansowanych Technologii, Poznański Park Technologiczno-Przemysłowy (PPTP), Centrum NanoBioMedyczne, czy Poznańskie Centrum Superkomputerowo-Sieciowe. Na schemacie (Rys. 4) zaznaczono powyższe instytucje w granicach miasta Poznania. Jak widać ich lokalizacja jest zróżnicowana - część znajduje się w bliskiej odległości od centrum miasta, inne - w obrębie kampusów uniwersyteckich, takich jak Kampus Morasko (UAM) czy Kampus Warta (Politechnika Poznańska). Zatem pod względem przestrzennym nie tworzą one jednolitego, wspólnego obszaru.

\section{DYSKUSJA}

Poznań aspiruje do bycia liderem w zakresie innowacji, zrównoważonego rozwoju i partycypacji społecznej. Dowodem na to jest inicjatywa Urzędu Miasta Smart City Poznań wspierana aplikacją o tej samej nazwie. Na oficjalnej stronie miasta czytamy: Smart city to dobrze funkcjonujące przyszłościowe miasto, oparte na aktywnym działaniu świadomych, niezależnych i decydujących o swoich 
losach obywateli (Smart City Poznań, 2021). Zaangażowanie społeczne jest główną osią idei inteligentnego miasta Poznania. Obszary ważne z punktu widzenia tej inicjatywy to: jakość życia, gospodarka, środowisko, społeczność, mobilność i cyfrowe miasto, a projekty realizowane w jej ramach powinny być innowacyjne, inkluzywne, integrujące i wykorzystujące narzędzia technologiczne. Dzięki aplikacji mieszkańcy miasta mogą łatwo i szybko zgłosić pomysł na ulepszenie miasta, zasygnalizować problem i jednocześnie mieć dostęp do zgłoszeń innych użytkowników aplikacji. Warto również wspomnieć o nowatorskim w skali kraju modelu 3D miasta Poznania, projekcie zrealizowanym w 2018 roku (z późniejszymi aktualizacjami). Model ten wspomaga planowanie przestrzenne miasta, ochronę środowiska, jest przydatnym narzędziem w zakresie konsultacji społecznych. Od 2013 roku z powodzeniem jest również realizowany budżet partycypacyjny oparty na modelu Porto Alegre (Kalisiak-Mędelska, 2016, s.112-113). Czy wspomniane działania rzeczywiście klasyfikują Poznań jako miasto inteligentne, a działania na rzecz polepszenia warunków życia są odczuwalne dla jego mieszkańców? Warto w tym miejscu zadać pytanie jaka jest właściwie definicja „miasta inteligentnego"? Pytanie to podniosła autorka publikacji Istota koncepcji smart city. Aktywność miasta Poznania na drodze do smart city - Ewa Łaźniewska. Badaczka przeanalizowała różne definicje tego pojęcia, wydobywając z nich cechy wspólne, takie jak: występowanie procesów innowacyjnych, korzystanie z wiedzy (szczególnie technologicznej), inteligentne zrównoważenie, ukierunkowanie na konkurencyjność i duże znaczenie jakości kapitału ludzkiego (Łaźniewska, 2020, s.109112). Wszystkie wymienione cechy realizują się w strategii rozwoju zarówno Porto Alegre (ZISPOA), jak i Smart City Poznań. Jedną z cech, którą wyszczególniła autorka wspomnianej publikacji jest również brak ograniczenia do konkretnych terytoriów (Łaźniewska, 2020, s.109). W tym kontekście Obszar Zrównoważonej Innowacji w Porto Alegre wyróżnia się i jest swego rodzaju novum, które warto poddać bacznej obserwacji. We wspomnianym artykule E. Łaźniewska podsumowuje swoje badania przeprowadzone na 2 tysiącach poznańskich studentów $\mathrm{m}$. in. słowami: Istotym czynnikiem stymulującym zachodzące zmiany w kierunku rozwoju inteligentnych miast jest proces „uczenia się”, który powinien być stymulowany poprzez różnego rodzaju akcje miast informujące o nowych rozwiązaniach technologicznych $i$ włączające społeczności miast w te procesy. Jak pokazują badania własne autorki tekstu, wiedza na ten temat wśród młodych ludzi nie jest rozwinięta (Laźniewska, 2020, s.115). Lukę pomiędzy staraniami władz miasta i aktywistów, a rzeczywistym zaangażowaniem mieszkańców w tworzenie miast przyszłości, jak pokazuje przykład Porto Alegre, może wypełnić Obszar Zrównoważonej Innowacji. ZISPOA jest strefą, w której w sposób zintensyfikowany materializują się założenia inteligentnego miasta przyszłości. Idea zrównoważonego rozwoju i innowacji otrzymała tam wyraźne ramy przestrzenne i czasowe, została zdefiniowana poprzez nazwę, własną markę oraz system identyfikacji wizualnej, dzięki temu jest rozpoznawalna - niemal namacalna w przestrzeni miasta. Według B. Cohena, badacza tematyki smart city, istnieją 3 generacje miast inteligentnych (Alves, Dias i Seixas, 2020, s.3), jego zdaniem trzecia generacja smart city to ta, która angażuje nie tylko firmy technologiczne i władze miasta, jak miało to miejsce w dwóch pierwszych generacjach, ale wyróżnia się inicjatywami z udziałem mieszkańców. Cechą nową w przypadku Porto Alegre jest ograniczenie, czy raczej wyznaczenie konkretnego terytorium. Nie jest to ograniczenie, które ma działać niekorzystnie na obszar, który znajduje się poza jego granicami - wytyczenie granic ma służyć intensyfikacji i materializacji działań, widocznych i rozpoznawalnych w przestrzeni miejskiej. OZI to laboratorium miasta inteligentnego w tkance urbanistycznej, spotkanie świata wirtualnego i innowacyjnych technologii z materią miasta, jego ulicami, chodnikami, budynkami, a co najważniejsze - z jego mieszkańcami. Zatem w oparciu o istniejącą definicję miasta inteligentnego autorka proponuje nową, zaktualizowaną o doświadczenie miasta Porto Alegre:

Inteligentne miasto to obszar zamieszkiwany przez świadomych, twórczych i zaangażowanych mieszkańców, którzy współpracują ze sobą w myśl zrównoważonego rozwoju, w celu poprawy jakości życia oraz szybkiego, innowacyjnego rozwiązywania pojawiających się problemów. Inteligentne miasto inwestuje w kapitał intelektualny mieszkańców, rozwój zaawansowanych technologii oraz atrakcyjność, przyciągając tym samym nowych, kreatywnych ludzi. Inicjatywy mieszkańców realizują się w przestrzeni publicznej, w której świat wirtualny i zaawansowane technologie spotykają się z materią miasta - są widoczne i czytelne dla mieszkańców. 
Wytyczenie obszaru zrównoważonej innowacji w mieście jest wyzwaniem i jednocześnie zaproszeniem dla urbanistów, architektów, projektantów produktu, grafików i innych zawodów kreatywnych do zabrania głosu w dyskusji nad wizją miast przyszłości. Głos ten powinien być odpowiednio przemyślany już na etapie studiów projektowych. Bardzo dobrym przykładem takich praktyk może być przedmiot Innowatyka realizowany w programie studiów Wydziału Architektury Politechniki Poznańskiej.

\section{PODSUMOWANIE}

W ramach podsumowania skonstruowano tabelę (Tab.3) porównującą ideę Obszaru Zrównoważonej Innowacji Porto Alegre z inicjatywą Smart City Poznań. Tabela nie ma charakteru oceniającego, jedynie opisujący obserwacje zawarte w artykule.

Tab 3. Zestawienie podsumowujące badania - porównanie ZISPOA i Smart City Poznań oraz danych ogólnych dotyczących obu miast, ich pozycji w rankingu GaWC w latach objętych badaniem (2015-2021). Źródło: opracowanie własne

\begin{tabular}{|l|c|c|}
\hline \multicolumn{3}{|c|}{ Dane dotyczące projektów } \\
\hline Kryterium & ZISPOA & Smart City Poznań \\
\hline Z inicjatywy władz miasta & nie $\times$ & tak $\checkmark$ \\
\hline Zaangażowanie organizacji rządowych & tak $\checkmark$ & tak $\checkmark$ \\
\hline Zaangażowanie organizacji pozarządowych & tak $\checkmark$ & tak $\checkmark$ \\
\hline Zaangażowanie środowiska akademickiego & tak $\checkmark$ & nie $\times$ \\
\hline Zaangażowanie przedsiębiorstw & tak $\checkmark$ & tak $\checkmark$ \\
\hline Wspieranie startupów & tak $\checkmark$ & tak $\checkmark$ \\
\hline Realizacja budżetu partycypacyjnego & tak $\checkmark$ & tak $\checkmark$ \\
\hline Wyznaczone terytorium w mieście $\times$ \\
\hline Informacyjna strona internetowa & tak $\checkmark$ & tak $\checkmark$ \\
\hline Aplikacja na urządzenia mobilne & tak $\checkmark$ & tak $\checkmark$ \\
\hline \multicolumn{1}{|c|}{ Dane ogólne dotyczące miast } \\
\hline Kryterium & Porto Alegre & Poznań \\
\hline Miasto akademickie & tak $\checkmark$ & tak $\checkmark$ \\
\hline Stolica regionu & tak $\checkmark$ & tak $\checkmark$ \\
\hline $\begin{array}{l}\text { Powierzchnia miasta (w granicach administra- } \\
\text { cyjnych) }\end{array}$ & 500 km² & 262 km² \\
\hline Liczba mieszkańców miasta & High Sufficiency & High Sufficiency \\
\hline Pozycja miasta w rankingu GaWC* 2016 & High Sufficiency & Gamma - \\
\hline Pozycja miasta w rankingu GaWC*iency & Gamma - \\
\hline Pozycja miasta w rankingu GaWC 2018 & 530000 \\
\hline
\end{tabular}


Obszar Zrównoważonego Rozwoju Porto Alegre to projekt konsolidujący ideę innowacyjnego i zrównoważonego miasta przyszłości. Jego ramy czasowe zostały określone na lata 2015-2030, obecnie jest w trakcie realizacji, ale już dziś można zaobserwować pozytywne efekty powołania tej inicjatywy. ZISPOA aktywnie angażuje środowisko akademickie, organizacje rządowe i pozarządowe, duże przedsiębiorstwa i kreatywne, innowacyjne startupy. OZI to oddolny i otwarty ruch społeczny, ale z silnym powiązaniem dyplomatycznym z rządem i środowiskiem akademickim. Projekty związane z tym obszarem są realizowane na bardzo dużą skalę, zarówno pod względem ilości biorących w nich udział osób, jak i międzynarodowy charakter tych przedsięwzięć. Jednocześnie materializują się w wyznaczonym obszarze w przestrzeni miasta, dzięki czemu są łatwo zauważalne i przynoszą szybkie korzyści. Prowokują współpracę w ramach lokalnych, sąsiedzkich społeczności. Umieszczenie idei zrównoważonej innowacji w istniejącym, faktycznym kontekście przestrzennym, angażuje urbanistów, architektów i wielu innych projektantów, których głos powinien być istotny w dyskusji na temat miast przyszłości. Obszar zrównoważonej Innowacji może pełnić rolę eksperymentu i modelowego wdrażania strategii zrównoważonego rozwoju w danym ośrodku miejskim. Poznań również pracuje nad osiągnięciem statusu miasta inteligentnego, realizując wiele inicjatyw, takich jak program Smart city Poznań, inwestując w startupy, innowacje, rozwijając parki technologiczne i inkubatory przedsiębiorczości. W stolicy Wielkopolski brakuje jednak wyraźnego obszaru, który byłby namacalnym efektem tych działań, laboratorium zrównoważonej innowacji, ustanowionym w danym miejscu i czasie. Brakuje również zakrojonego na szeroką skalę projektu wyraźnie angażującego środowisko akademickie. Wywołanie ruchu podobnego do ZISPOA w Poznaniu, mieście o tak dużym kapitale intelektualnym, określenie ram czasoprzestrzennych takiej inicjatywy mogłoby być szansą na transformację stolicy Wielkopolski w lidera zrównoważonej innowacji w skali europejskiej, a nawet globalnej.

\section{BIBLIOGRAPHY}

Alves, M.A.; Dias, R.C.; Seixas, P.C. Smart Cities no Brasil e em Portugal: o estado da arte. urbe. Revista Brasileira de Gestão Urbana 2019, 11, p. 3 (DOI: https://doi.org/10.1590/2175-3369.011.e20190061)

Badam Baza Danych Miasta. Available online: https://badam.poznan.pl/en/2018-studenci/ (accessed on 16 September 2021).

Badam Baza Danych Miasta. Raport o stanie Miasta Pozania za 2020 rok - podsumowanie. Available online: https://badam.poznan.pl/wp-content/uploads/2021/05/Podsumowanie-Raport-o-stanie-miasta-za-2020.pdf (accessed on 16 September 2021).

Gentil, F.D.S. A formação de engenheiros e arquitetos e as oportunidades no Mercado de construções sustentáveis, Postgraduate Degree, Universidade Tecnológica Federal do Paraná, Curitiba, 2018, p. 39.

Global Urban Development. Available online: https://www.globalurban.net/porto-alegre-brazil (accessed on 13 September 2021).

GUS, Ludność. Available onlin: https://poznan.stat.gov.pl/dane-o-wojewodztwie/stolica-wojewodztwa-994/ludnosc-1154/ (accessed on 3.11.2021).

IBGE Cidades. Available online: https://cidades.ibge.gov.br/brasil/rs/porto-alegre/panorama (accessed on 14 September 2021).

Kalisiak Mędelska, M. Budżet obywatelski w Polsce. Analiza porównawcza Łodzi i Poznania. Prace Naukowe Uniwersytetu Ekonomicznego we Wrocławiu 2016, 443, pp. 112-113. (DOI: https://doi.org/10.15611/pn.2016.443.10)

Kuriata, A. Budżet partycypacyjny jako przejaw demokracji uczestniczącej w samorządzie lokalnym. Województwo - region - regionalizacja. 15 lat po reformie terytorialnej i administracyjnej. Korczak, J.; Prawnicza i Ekonomiczna Biblioteka Cyfrowa, Wrocław, Poland, 2013; p. 41. 
Leite, C. Cidades sustentáveis, cidades inteligentes: Desenvolvimento sustentável num planeta urbano, 1st ed.; Bookman. Porto Alegre, Brazil, 2012; p. 14.

Łaźniewska, E. Istota koncepcji smart city. Aktywność miasta Poznania na drodze do smart city. Rozwój Regionalny i Polityka Regionalna 2020, 48, pp. 109-115. (DOI: https://doi.org/10.14746/rrpr.2019.48.07)

Scatolin, D.; Misael, M.C. Uma nova estratégia de desenvolvimento sustentável: alguns pontos para o debate. A Revista Economia \& Tecnologia 2011, 7(3), p. 7. (DOI: https://doi.org/10.5380/ret.v7i3.26618)

Smart City Poznań. Available online: https://www.poznan.pl/mim/smartcity/ (accessed 17 September 2021).

Streck, D.R.; Pitano, S.D.C.; Moretti, C.Z.; Educar pela participação, democratizer o poder: o legado freireano na gestão pública. Educação em Revista 2017, 33, p.13. (DOI: https://doi.org/10.1590/0102-4698167880)

The World According to GaWC 2020. Available online: https://www.lboro.ac.uk/gawc/world2020t.html (accessed on 16 September 2021).

Urban Systems. Available online: https://www.urbansystems.com.br/ (accessed on 15 September 2021).

Urząd Statystyczny w Poznaniu. Available online: https://poznan.stat.gov.pl/vademecum/vademecum_wielkopolskie/portrety_miast/miasto_poznan.pdf (accessed on 15 September 2021).

Weiss, M.; Sedmak-Weiss, N.J.; Rodriguez, Y.E. A Report to the Rio Grande do Sul State Government (AGDI) and the World Bank, by Global Urban Development (GUD) and Unisinos, applying GUD's Metropolitan Economic Strategy, Sustainable In- novation, and Inclusive Prosperity Framework, Porto Alegre, Brazil, 2015. Global Urban Development. Available online: https://globalurban.org/2015_RS_LEAPFROG_ECONOMIC_STRATEGY_Executive_Summary.pdf (accessed on 13 September 2021).

Wiechetek, P. "(South) American Dream": wzlot i upadek brazylijskiej wersji “Nowego Ładu”. Ameryka Łacińska Kwartalnik Analityczno-Informacyjny 2020, 4(106), pp. 26-30. (DOI: https://doi.org/10.36551/20811152.2019.106.02)

ZISPOA Info. Weiss, M. The Porto Alegre Sustainable Innovation Zone (ZISPOA), 2019. Available online: https://www.zis- poa.info/documentos (accessed on 13 September 2021).

\section{AUTHOR'S NOTE}

Ewa Angoneze-Grela, architect, graduate of Poznan University of Technology. Opening of the doctoral thesis (2019) with the title: Architecture - Migrations - Identity. Study of half-timbered architecture in the historic Colônia Santo Ângelo region in Brazil against the background of the 19th century emigration wave from West Pomerania (supervisor: prof. dr hab. inż. arch. A.Bonenberg). Scientific interests: architecture of migration, brazilian cities, urbanisation and public spaces, architecture of information.

\section{O AUTORZE}

Ewa Angoneze-Grela, architekt, absolwentka Politechniki Poznańskiej. Otwarcie przewodu doktorskiego (2019) o tytule: Architektura - migracje - tożsamość. Studium architektury szachulcowej historycznego regionu Colônia Santo Ângelo w Brazylii na tle XIX-wiecznej fali emigracyjnej z Pomorza Zachodniego (promotor: prof. dr hab. inż. arch. A. Bonenberg). Zainteresowania naukowe: architektura migracji, miasta brazylijskie, urbanizacja i przestrzenie publiczne, architektura informacji.

Contact | Kontakt: ewa.grela@put.poznan.pl 